\title{
Trade Ceramics from the Goto Islands (Japan), Circa Sixteenth to Early Seventeenth Century: The Yamami Underwater Site (Ojika) and Related Issues
}

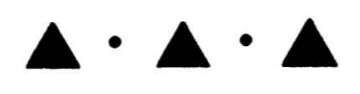

\section{BARBARA SEYOCK}

\section{INTRODUCTION}

ONE FIELD IN WHICH ART HISTORIANS as well as archaeologists have recently been interested-and one that has already developed its own research tradition both in East Asia and in the West - relates to the medieval and early modern articles collectively termed "trade ceramics." Trade ceramics comprise, among other objects, high-fired stoneware (Jap. tōjiki 陶磁器), celadon (Jap. seiji 青磁), and porcelain (Jap. jiki 磁器) from China, Korea, Southeast Asia, and Japan. The term itself denotes the handling of the items as export commodities that were traded across the sea, rather than the quality of the wares. Pieces found in their country of origin will thus not necessarily fall into the category of trade ceramics, although the particular kiln might have produced ceramics for the export market. It is the far-traded commodity that bears information on the structures and mechanism of the maritime exchange that connected the nations bordering the East China Sea (Jap. Higashi Shina-kai 東シナ海) in premodern times. As Renfrew and Bahn (1991:320) emphasize in their general discussion of archaeological method and theory, "the study of traded goods themselves and the identification of their sources" is key to investigating the exchange between cultures or premodern polities. In analyzing the traded goods, moreover, we may gain information on the social and economic contexts of exchange.

In East Asia, where goods of all kinds have been traded from ancient periods on, even along long-distance routes, sea trade began to flourish during the Southern Song (南宋) period (1127-1279). The demand for Song period ceramics in Japan and elsewhere was already high, but it was only during the late medieval (ca. fourteenth to sixteenth centuries) and early modern periods (ca. seventeenth to early nineteenth centuries) that trade ceramics evolved into one of the decisive factors of maritime commerce in the South China Sea as well as in the East China

Dr. Barbara Seyock is a research fellow at the University of Munich, Department of Asian Studies, Institute of Chinese Studies. 
Sea. In the fifteenth and sixteenth centuries, despite the official maritime trade prohibition policy of early Ming (明) China (1368-1644), Chinese and Southeast Asian junks with cargoes of up to tens of thousands of pieces of porcelain and glazed stoneware sailed between the coasts of South China, Thailand, and Vietnam and the bustling ports of Indonesia, Malaysia, and the Philippines (Desroches 1997 : 132-136; Goddio 2002a : 4; Lam 2002).

Junks also sailed north, passing the Taiwan Strait and up to the port cities of the Japanese archipelago and the South Korean coast, either crossing the East China Sea directly from eastern Chinese ports such as Ningbo (寧波) or following the route along the Ryūkyū (琉球) Islands to Satsuma (薩摩) in southern Kyūshū (九州) and farther north. During the sixteenth century, the maritime trade of this region began to include European merchants and ships, thus connecting the China Seas to the Western Hemisphere and its emerging world trading systems (Neave-Hill 1975:159-160; Richards 1995:4).

Much of the ceramic material traded in those days never disappeared into the soil. It was handed down from generation to generation as heirlooms, kept in private collections, and eventually may have found its way to public display. In western Europe, admirers of Chinese porcelain have been collecting china or chinaware - the terminology itself mirrors the influence of these commoditiessince the sixteenth century, when Portuguese sailors first brought back Kraak (after Port. carracca, ship) porcelain pieces from Chinese markets in larger amounts (Baer 1973:50; Scott 2002:93-94). Art history museums all over the world-the Victoria and Albert Museum in London, the Ashmolean Museum in Oxford, the Topkapi Palace in Istanbul, and the Ceramic Museum in Ōsaka, to name only a few-keep exquisite collections of East Asian trade ceramics, in particular Chinese porcelain industrially manufactured in large quantities for export reasons (Rawson and Portal 1992:256-291). In the last decades, the salvage of sunken junks-mainly in the South China Sea and often carried out by international teams of underwater archaeologists - has added hundreds of thousands of trade ceramics to the global collection as well as to the art market, many of them in well-preserved condition. ${ }^{1}$

\section{TRADE CERAMICS IN JAPAN}

For the western Japanese waters, which are the focus of the following study, there has been no wreck find up to the present day, although the Kyūshū and Okinawa Society for Underwater Archaeology-founded in 1986 and recently renamed Asian Research Institute of Underwater Archaeology (ARIUA)-began to survey the coastlines of the Genkai Sea (玄海) (northern Kyūshū) in the early 1990s (Nogami 2003:485-494; http://www.h3.dion.ne.jp/ uwarchae). The situation is different for the South China Sea and even for neighboring South Korea, where the finds of the Shin'an (新安) and Wando (莞島) wrecks attracted worldwide attention (Fig. 1). The former, a fourteenth-century Chinese merchant ship with a cargo of over 20,000 pieces of fine ceramics and 6 million Chinese coins, ${ }^{2}$ is supposed to have been on its way to Japan when it met its fate near Shin'an on the southwest Korean coast. The wreck was raised between 1976 and 1984, and the extensive investigation generated the founding of the Mokp'o Conservation Laboratory of the National Research Institute of Cultural Properties, which in 


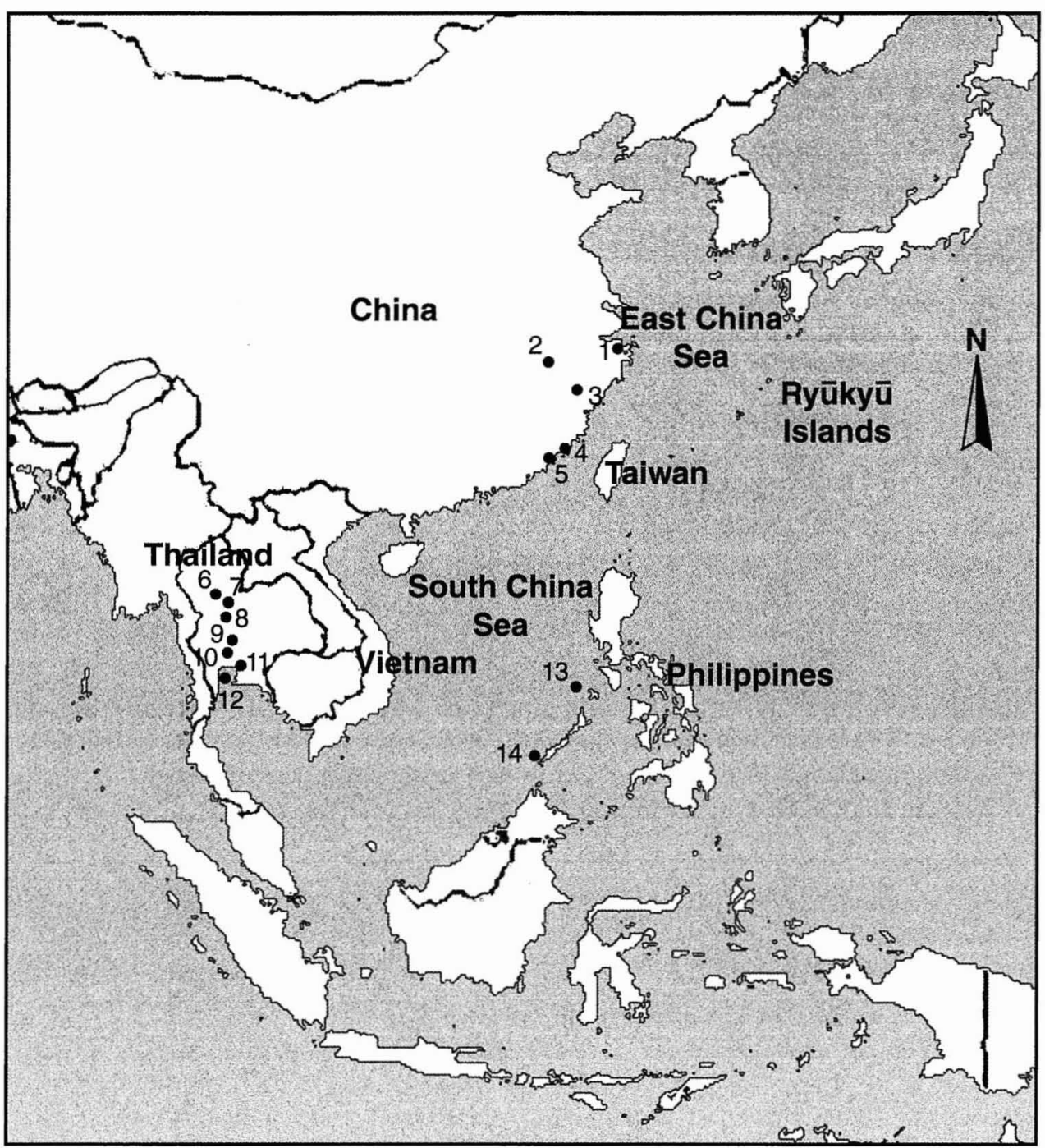

Fig. 1. Map of China and Southeast Asia and the location of sites and kilns mentioned in the text: 1: Ningbo; 2: Jingdezhen kilns; 3: Longquan kilns; 4: Quanzhou kilns; 5: Tongan kilns; 6: Sisatchanalai kilns; 7: Sukhothai kilns; 8: Pitsanulok kilns; 9: Singburi kilns; 10: Suphanburi kilns; 11: Ayutthaya; 12: Ko Khram wreck; 13: Lena shoal wreck; 14: Royal Captain wreck.

1994 became the National Maritime Museum (Mokp'o 목포, South Korea). The Wando wreck was recovered in 1984. It turned out to be an eleventh-century Korean coastal merchant ship carrying more than 30,000 pieces of ceramic wares. Other underwater discoveries of celadon cargoes near the South Korean coasts followed in 1995-1996 (Torip'o 道里浦) and 2002-2003 (Piando 飛雁島) (Kungnip Haeyang Yumul Chŏngsigwan 2003:20-85). The number of underwater site finds is growing also in Japan, and as archaeologists nowadays pay much more attention to what sources the seafloor may hold for them, it should 
be just a matter of time until the first wreck of a Chinese or Southeast Asian trading ship will be identified in the vicinity of the Japanese Islands. ${ }^{3}$

Up to now, much of the archaeologically recovered ceramic material associated with the centuries of world trade in Japan has come from the large seaports, such as Hakata (博多) (northern Kyūshū), Nagasaki (長崎) and Hirado (平戸) (western Kyūshū), and Sakai (境) (central Honshū 本州). Other sites comprise smaller trading ports and stations, partly connected to pirate activities (Seyock 2005) - castles, castle towns and mansions of the warrior class, temples and shrines (which still keep fine ceramics as treasures), settlement sites, and burial places.

The excavated material, especially from the ports, may well amount up to tens of thousands of pieces now stored in the numerous archaeological facilities and archives across the country. Japan certainly has one of the most active archaeological scenes in the world. In the mid-1990s, during the peak of the archaeology boom in Japan, 10-12,000 sites were investigated each year (Seyock 2004:2). $\mathrm{Up}$ to a few thousand site reports and books are published yearly, and although late medieval and early modern finds comprise only a minor-though recently increasing - part of the excavation activities, keeping up to date with the latest data about trade ceramics bears great difficulties, even for the researcher based in Japan. The medieval Hakata site cluster (Hakata iseki-gun 博多遺跡群) alone, to name a prominent example, experienced at least 150 excavation campaigns in the last 20 years, possibly more, resulting in more than a hundred site reports and many additional publications. Not all the campaigns produced trade ceramics, but many did, and often in considerable numbers of several hundred shards.

This study therefore has to refrain from the attempt to give a synthesis of trade ceramic finds in Japan. The archaeological interest in traded ceramics is a rather recent development, and not surprisingly, comprehensive approaches are still missing. ${ }^{4}$ For decades the Japanese research in trade ceramics has been carried out largely in the framework of art history. Significant archaeological research in this field started only in the 1990s (Kaneko 2004:54), and it is still mainly concerned with typological and chronological questions.

The Yamami underwater site (山見沖海底遺跡), which is the focus of this article, will instead serve as a case study in trade ceramic research. It is a significant find in both its location and assemblage, and it raises essential questions regarding not only the reconstruction of trade networks and shifting trade routes but also concerning the general analytical approach toward trade ceramics.

\section{TRADE CERAMICS FROM THE YAMAMI UNDERWATER SITE}

\section{Location and Survey}

The Yamami underwater site, designated 7 on Figure 2, is situated near Ojika Island (小值賀島), a part of the Gotō Islands (五島列島) (Nagasaki Prefecture), in a geographic region that lies far from the premodern urban and military centers of Japan. One is therefore at first glance inclined to consider the small isles of the Gotō Island chain as a mere periphery in both their location and in the general historical development of Japan. However, as the archaeological complexes show, the Gotōs have participated in an international trading network from ancient periods on. 


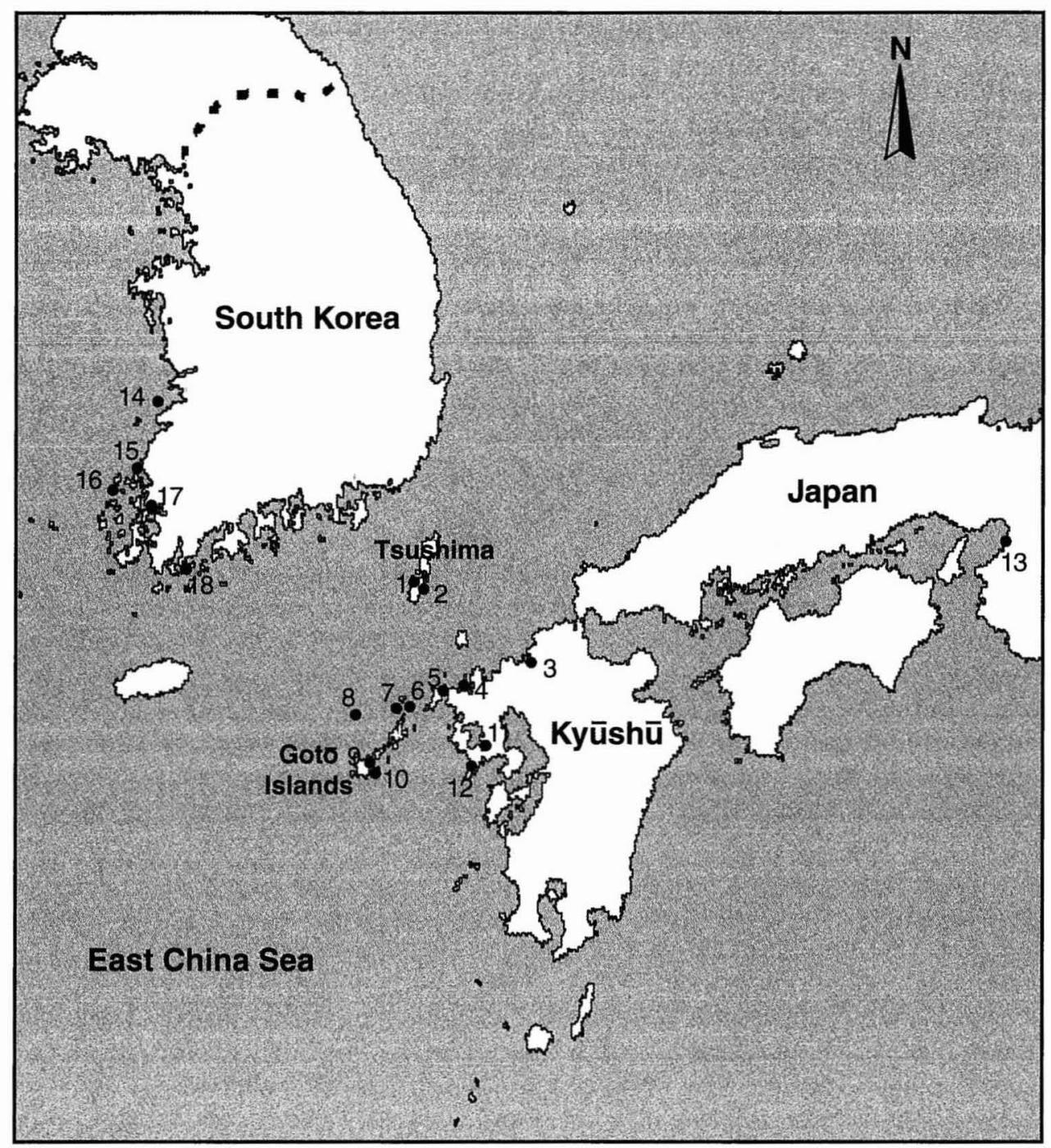

Fig. 2. Map of Western Japan and South Korea and the location of sites mentioned in the text: 1: Mizusaki; 2: Izuhara; Ima and Karō elite residential site; 3: Fukuoka (Hakata); 4: Takashima; 5: Hirado; 6: Okinokamishima shrine; 7: Yamami underwater site, off Ojika Island; 8: Körai Shoal; 9: Ishida Castle; 10: Ōhama; 11: Kushima Castle; 12: Nagasaki (Dejima); Sakuramachi; Manzaimachi; Sakaemachi; 13: Sakai; 14: Piando; 15: Torip'o; 16: Shin'an wreck; 17: Mokp'o; 18: Wando wreck.

Situated west of the northwestern Kyūshū coast, the Gotōs apparently functioned as the starting point for direct sea travel across the East China Sea over the shortest distance between the Chinese mainland and Japan. The nearest seaports of the Japanese main islands-from a Chinese perspective, the ports of Nagasaki and Hirado-lay in the vicinity of the Gotōs. While Hakata (today's Fukuoka) prospered as the main seaport for trade with China and Korea throughout the Muromachi (室町) period (1333-1568) and up to the early Tokugawa (徳川) 
(1603-1868) years, just as Hirado benefited from Portuguese ships sailing in for about a hundred years from the second half of the sixteenth century on, Nagasaki served as the only licensed international port after the trade prohibitions of the 1630s until the breakdown of the Tokugawa realm in the second half of the nineteenth century. The Gotōs thus lay within direct reach of the centers of international exchange during the centuries of world trade in East Asia. Ships carrying envoys on their way to China stopped here from the eighth century on, and international merchant ships started coming to the Gotōs as early as the ninth century.

A center of medieval and early modern site distribution is located on Ojika Island, one of the smallest islands of the Gotōs and the second northernmost of the chain of islands. Although Ojika covers an area of only $12.95 \mathrm{~km}^{2}$, it is characterized as the entrance to the East China Sea. About 71 percent of all the trade ceramics on the Gotōs have been found at Ojika sites, while 22 percent come from the neighboring Uku Island (宇久島) (Tsukahara 2003).

Some pottery shards originating from sixteenth- or seventeenth-century Thailand (Siam), found by a diver and delivered to the educational board of Ojika Island in 1992, prompted the preparation of an archaeological survey of the Yamami underwater site, which was eventually carried out by the Kyūshū and Okinawa Society for Underwater Archaeology and the Ojika City Board of Education in the summer of 2001. The site is situated along a small reef, about $100 \mathrm{~m}$ off the eastern shore of Ojika Island, at Karamizaki (唐見崎) Ward. In a sea depth of approximately $5 \mathrm{~m}$, ceramic shards were scattered throughout an area of c. 30 $\mathrm{m}$ by $80 \mathrm{~m}$. Within this area, a center full of shards was evident between two larger submerged rocks. Although these circumstances, as well the general location-close to the coast and along the former China-Gotō-north Kyūshū shipping route-suggest the shipwreck of a trading ship passing the narrow strait between Ojika and Nozaki (野崎島) Islands, no signs of a hull could be found. Due to the reports of some local fishermen, who complained of their nets being torn by anchors apparently lying on the seafloor around Karamizaki Peninsula, some additional diving excursions were conducted in search of ancient anchor pieces. Several anchor stones of medieval trading ships had been discovered earlier around Ojika Island, their shape suggesting they are of Chinese origin, but nothing has yet been found in the direct vicinity of the Yamami site. The details about the size of the sunken vessel, its provenance, or destination, therefore, remain vague. Even the question of whether the features of the site actually fit into the perception of a single ship's wreckage has to be left unanswered at the moment.

The complex recovered in the course of the underwater survey comprises mainly Thai stoneware (Jap. Tai tōki タイ陶器) and some Chinese blue-andwhite porcelain pieces (Jap. seika-jiki 青花磁器). The ceramics were possibly produced between the early sixteenth and the early seventeenth centuries. Some fragments are thought to belong to Vietnamese specimens of about the same period, whereas two Hizen (肥前) ware shards come from nineteenth-century northern Kyūshū. They may have no connection to the main complex of the site. All in all, 87 ceramic shards have been collected from the seafloor (KyūshūOkinawa Suichū Kōkogaku Kyōkai 2002 [hereafter Kyūshū-Okinawa 2002]; Nogami 2003 : 490-494; see also http://www.h3.dion.ne.jp/ uwarchae). 

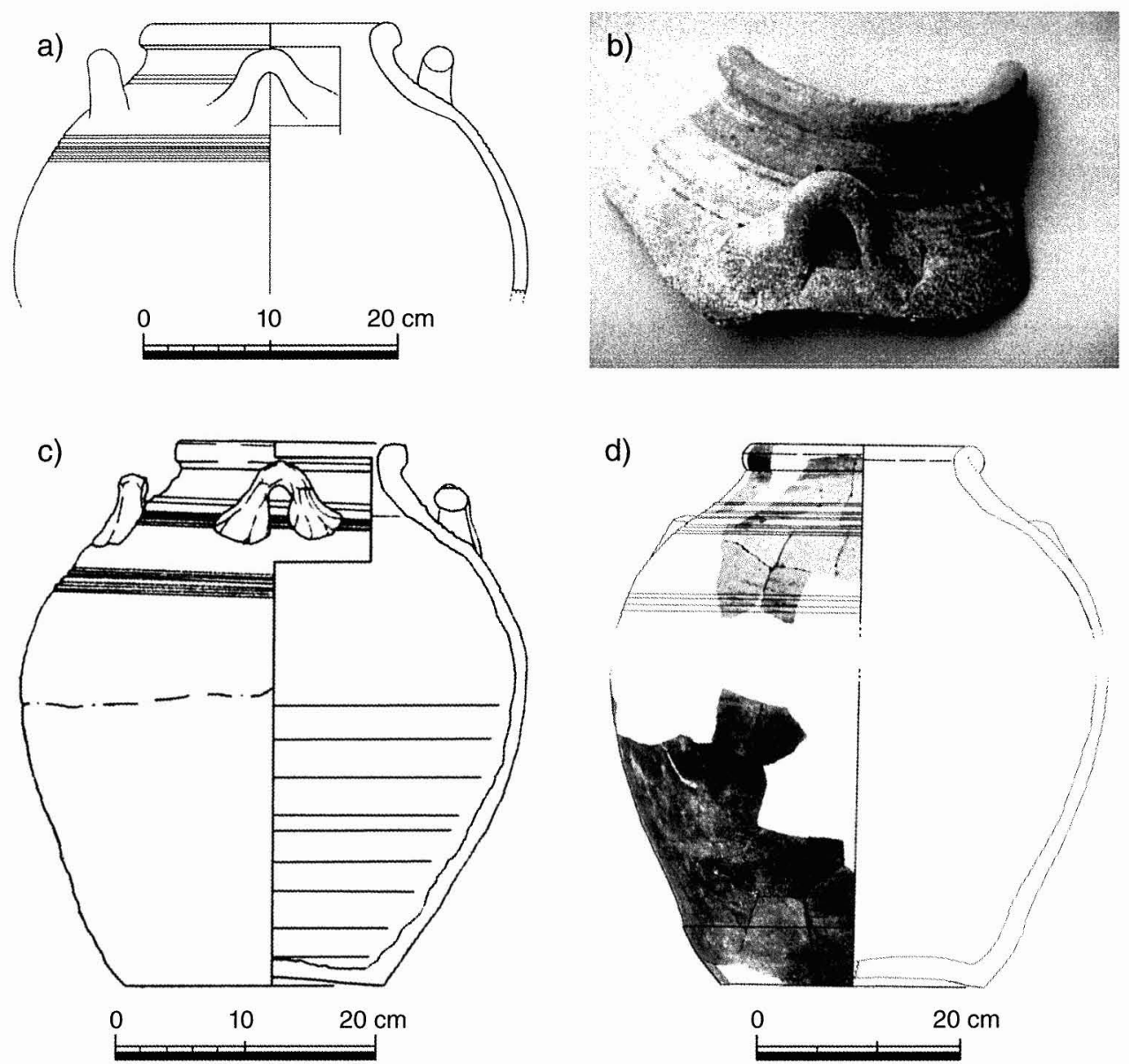

Fig. 3. Thai jar fragments from Japanese sites: $a$ and b: Yamami site (after Kyūshū-Okinawa 2002:16, fig. $5 / 3$ and pl. 27); c: Sakai moated city site (after Cort 1993:38, fig. 39/4); d: Ima and Karō elite residential site (after Nagasaki-ken Kyōiku linkai 2004 :28, fig. 29/10).

\section{Thai Wares}

The Yamami site yielded 74 Thai stoneware and earthenware shards that seem to belong to 72 different vessels. Among them, 17 stoneware jars (Jap. tōki tsubo 陶 器畫) have been identified, most of them showing four horizontal lug handles (Fig. 3a,b). "Jar" in this context refers to a vessel that was most likely used as a storage container for food or other goods, even for smaller pieces of ceramic ware such as teacups and dishes, which were highly esteemed, especially by Japanese customers.

Thai wares were not only widely spread in Southeast Asia; they also reached the Japanese archipelago in certain quantities. The undiminished demand for high-fired stoneware and porcelain around the China Seas opened the markets for pieces from Southeast Asia in times when Chinese wares were difficult to 
purchase. The kilns of central Thailand (Sukhothai, Sawankhalok/Sisatchanalai, Pitsanulok) especially benefited from this situation (see Fig. 1). By the middle of the fourteenth century, the Sukhothai kilns produced export ceramics, traded along networks already established by Chinese merchants. Despite the political turmoil of the early fifteenth century, which brought an end to the Sukhothai Kingdom, the production of the respective kilns seems to have reached its heights only in the second half of the fifteenth century (Brown 2000:58; Richards 1995:17).

Roxana M. Brown $(2000: 58)$ places particular emphasis on the fact that at Philippine and Indonesian sites from the fifteenth to the mid-sixteenth centuries, "Thai wares often comprise 20 percent and sometimes even 40 percent of the ceramic finds," which indicates the success of Thai wares throughout Southeast Asia. In Japanese complexes, although quite common, the percentages of Thai ware shards are much lower.

From the sixteenth century on, the kilns of the Noi River region gained growing importance for the export market. ${ }^{5}$ The Yamami storage jars are supposed to have been manufactured there during the late sixteenth to early seventeenth centuries. The Noi River kilns were possibly "the major source of stoneware storage containers" for the period of the Ayutthaya Kingdom (1367-1767) in southern Thailand (Cort 1993:37).

One can suggest a close typological connection between the four-lug-handled jars of the Noi River region and the earlier examples originating from the kilns of Sawankhalok/Sisatchanalai and Pitsanulok. Brown (2000:96) advocates the possible founding of the Singburi Province kilns by "potters from the earlier site"namely Pitsanulok. The kilns of Pitsanulok were active from the fifteenth to the mid-sixteenth centuries and produced mostly unglazed stoneware jars, "largely in Sawankhalok tradition" (83). Alternatively, Dick Richards (1995) sees the origin of the Singburi techniques in the Sukhothai industry. He mentions finds of Singburi wares in maritime South Asia, on the Australian coast, and in Japan (17). ${ }^{6}$

Comparable vessels were actually recovered from the Sakai moated city (Sakai kangō toshi 堺環濠都市) site (Fig. 3c). The port city of Sakai (堺) was one of the most important trade centers in premodern Japan (Kyūshū-Okinawa 2002:14, 23-24, 43). Other examples of Noi River-type jars turned up at several other sites in central Japan (Wakayama 和歌山, Ōsaka 大阪, Hyōgo 兵庫, Shiga 滋賀, and Fukui 福井 Prefectures), as well as in the cities of Öita 大分 and Fukuoka 福 岡 (Hakata) on Kyūshū (Morimoto 2000:127-128). A recently excavated storage jar comes from the Ima and Karō elite residential site (今屋敷家老屋敷跡) in Izuhara (篇原) (Fig. 3d), a former mansion site of the Sō family (Jap. Sōke 宗家), the feudal lords of Tsushima (対馬) Island (Nagasaki-ken Kyōiku Iinkai 2004 : 28, 33).

For most of these Thai jar finds in Japan, a production date of late sixteenth to early seventeenth centuries is assumed, thus supporting the dates for the Yamami finds. Some jars found at sites in Shimane Prefecture (島根県) and Kyūshū (Kurume City 久留米市 and Hakata), said to come from the same kiln clusters of the Noi River region, nevertheless have been dated to the late fifteenth to midsixteenth centuries. The Thai wares of this earlier period, according to Morimoto's analyses, have reached Japan via the Ryūkyū Islands, which were then the main exchange center for Southeast Asian goods. A high percentage of earlier Thai ware finds comes from Okinawa (沖縄) (Ryūkyū Islands) or Kagoshima (鹿 
児島) at the southern tip of Kyūshū. Historical sources show that more than 150 ship voyages to Thailand were carried out by Ryūkyūans between 1385 and 1570. In the latter half of the sixteenth century, the exchange center for Thai wares moved to Sakai in central Japan (Guy 1993b:8; Kaneko 2004; Morimoto 2000:126-127).

Hayashida Kenzō (林田憲三) and Tsukahara Hiroshi (塚原博), having been in charge of the Yamami site survey and documentation, identified the obvious similarities between the Yamami jars and finds from several wreck sites in the South China Sea and elsewhere. The wreck of the Dutch vessel Witte Leeuw, for example, carried comparable jars said to have been made at Singburi kilns (Kyūshū-Okinawa 2002:14; see also Brown 2000:96; van der Pijl-Kete $1982: 239)$. The ship sank near St. Helena in the year 1613, which provides us with a fixed date for the ceramic complex.

The jar shards of Yamami are mostly unglazed, with small, dark spots in the light gray paste, a typical feature of Thai wares. Some shards show traces of black glaze or black color on the surface. The cooking bowls (Jap. hachi 鉢), of which 13 incomplete pieces have been identified, are unglazed as well, with grayish to reddish bodies. The bowls have flat bases and wide mouths with S-shaped rims. The mouth diameters range from approximately 21 to $31 \mathrm{~cm}$ (Fig. 4a).

Two small stemmed mortars (Jap. ashitsuki usu 足付臼) are believed to originate from the Ayutthaya Kingdom (Fig. 4b). Since three lids (Jap. futa 蓋) have been found-one of them apparently belonging to the fragment of a jar of the (Jap.) hannera (ハンネラ) type, usable as a freshwater container (Fig. 4c), as well as two shards possibly belonging to a portable kitchen oven-one can suggest an

a)
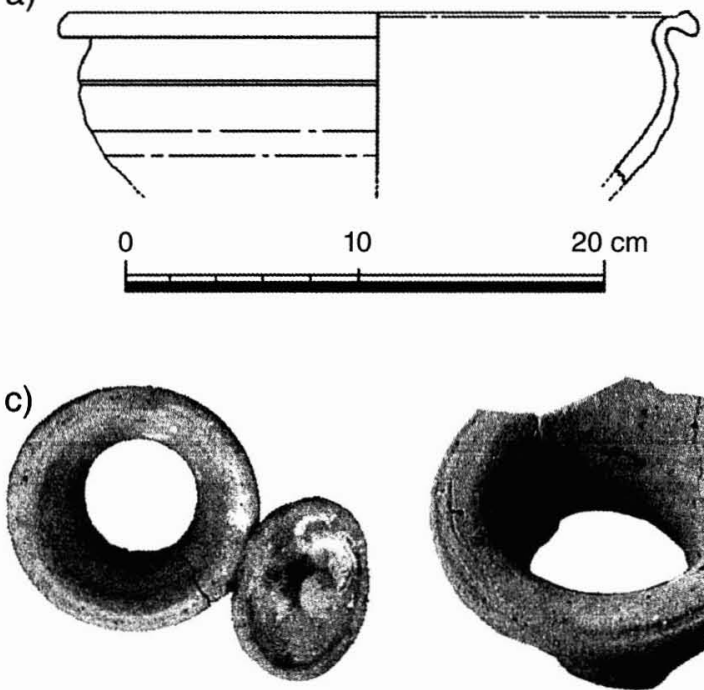

b)

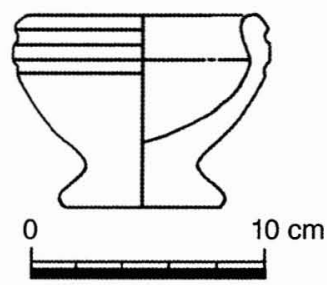

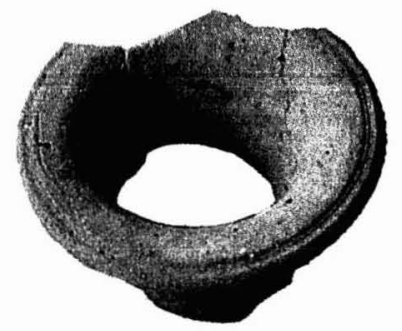

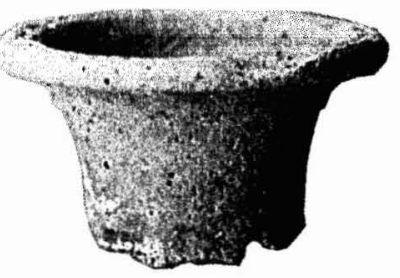

Fig. 4. Thai ware from Yamami site: a: stoneware cooking bowl (after Kyūshū-Okinawa 2002:18, fig. 7/19); b: earthenware mortar (after Kyūshū-Okinawa 2002:19, fig. 8/33); c: different views of the mouth part of an earthenware hannera with lid (photos: Seyock 2004, Ojika History and Folk Museum). 
original position of these utensils on the deck of the ship, where they were part of assemblages for everyday usage (Kyūshū-Okinawa 2002:20-24). For the fourlugged storage jars, on the other hand, Hayashida and Tsukahara assume an additional usage as a sort of ballast, positioned at the bottom of the ship (KyūshūOkinawa 2002:38).

Cargoes recovered in the region of the China Seas, however, exhibit a different picture. The Koh Khram jars are believed to have been "originally set on the deck of the ship" (Brown 1975:364), just as the Vietnamese stoneware jars from the Lena shoal junk apparently "had been stored on a quite high level, perhaps even on the deck" (Goddio 2002a:38), thus strengthening the idea of an ondeck position of the Yamami storage jars also.

\section{China Wares}

The blue-and-white porcelain pieces discovered at Yamami are said to date from the second half of the sixteenth century. They were probably produced in a kiln of Jingdezhen (景德鎮) (Jiangxi Province 江西省) in China, famous for blue-andwhite wares.

Porcelain production in Jingdezhen began as early as the tenth century. Due to the rich kaolin deposits in the vicinity of the town, the availability of wood for the firing, and (given a location on the south bank of the Chang River) the convenient transport conditions, Jingdezhen at that time developed into one of the largest industrial centers for ceramic and porcelain production, and it remains so today. The ceramic industry particularly flourished during the Ming dynasty, when porcelain of the highest quality was ordered in large amounts for use by the imperial household and other government institutions (Pierson 2002:59-61; Vainker 1992:238-240).

Monique Crick $(1997: 147)$ tells the story of a family business kiln that received orders from the imperial household to deliver as many as 50,000 pieces in the year 1436. For the year 1577, we learn about imperial orders given to Jingdezhen kilns for a total of 174,700 pieces (Ledderose 2004). Jingdezhen kilns produced likewise for the export markets, which were expanding rapidly after the first Portuguese ships entered the China Seas in the sixteenth century. In the seventeenth century, the ships of the Dutch East India Company (VOC) contributed much to the trade in Chinese porcelain. A VOC ship, which sank in 1640, contained 25,000 pieces of blue-and-white wares for the European market (Rawson and Portal 1992:279).

The blue-and-white wares found at Yamami are of diverse quality. The neck part of a bottle (Jap. kame 瓶) (Fig. 5a,b), or possibly a vase, shows clearly divided decoration fields arranged in horizontal bands, with pictures of roughly outlined plants and flowers in underglaze cobalt blue (Kyushū-Okinawa 2002:23). The uppermost extant decoration band depicts upright, lancetlike banana leaves, thus faintly reminiscent of the decoration of the world-famous "David vases" made in 1351 (Hesemann 1998:188-189). The Yamami bottle decoration, however, although apparently drawing on the earlier style, is far less accurate in its workmanship. The intensive blue filling color appears somewhat blurred; it widely surpasses the darker contours of the motives. The irregular shape of the bottle, on the other hand, with a double-twisted tail somehow resembling an eggplant, 

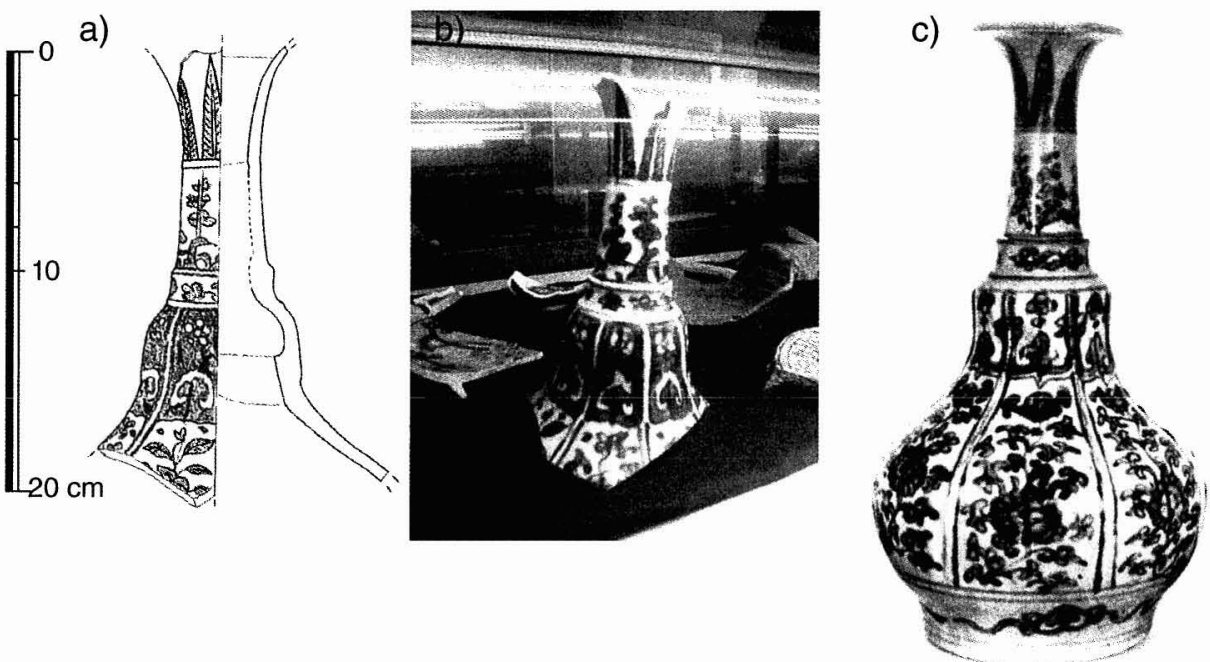

Fig. 5. Chinese blue-and-white porcelain: a and b: bottle fragment from Yamami site (after KyūshūOkinawa 2002:19, fig. 8/45; photo: Seyock 2004, Ojika History and Folk Museum); c: bottle of unknown provenance (after Sotheby \& Co. 1974:26, fig. 401).

matches a Wanli (萬歷) period (1573-1620) blue-and-white bottle from the Pierpont Morgan collection (Bushell 1919:32, and fig. 21), while a similarly "unusual" piece offered by Sotheby's in 1974 is very close to the Yamami example both in shape and design (Fig. 5c). The sixteenth-century bottle is said to have been inspired by a Near Eastern metal shape (Sotheby \& Co. 1974:51).

A porcelain piece of different shape but similar design comes from the Dejima (出島) excavations in the city of Nagasaki. Dejima, the artificial island constructed in the port of Nagasaki in the 1630s, was the only place where Europeans, namely the Dutch, were allowed to pursue their trade business after 1641. The original spot of the Dutch Factory (Jap. Oranda shokan オランダ商館), swallowed by landfill and the necessities of a growing city during the Meji period (1868-1912), has experienced some major excavation campaigns and reconstruction work in recent years, during which many structural remains and artifacts, especially ceramics, have come to light. The find under review here is a blue-and-white dish (Jap. sara III) shard, with a cobalt blue decoration of encircled flowering plants on the rim and the picture of a songbird framed by flowering plants in the center of the dish (Fig. 6a). Here again, the color surpasses the contours. The piece is said to originate from a Jingdezhen kiln in a period between 1590 and 1630, and due to this date it should have reached the place of its final destination in times when the Portuguese were still trading at the Nagasaki port (Nagasaki Shiritsu Hakubutsukan $2000: 53$ ).

A bottle in kendi shape, kept by the Museum of East Asian Art in Cologne (Germany), may hold some further information relating to both the date of the Yamami bottle and, more importantly, for which markets such pieces were originally meant. The kendi bottle - a type of ceramic with a voluminous body, the typical kendi spout, and a long neck-is decorated with several horizontal and some additional vertical motif bands in underglaze cobalt blue, with floral design 
b)
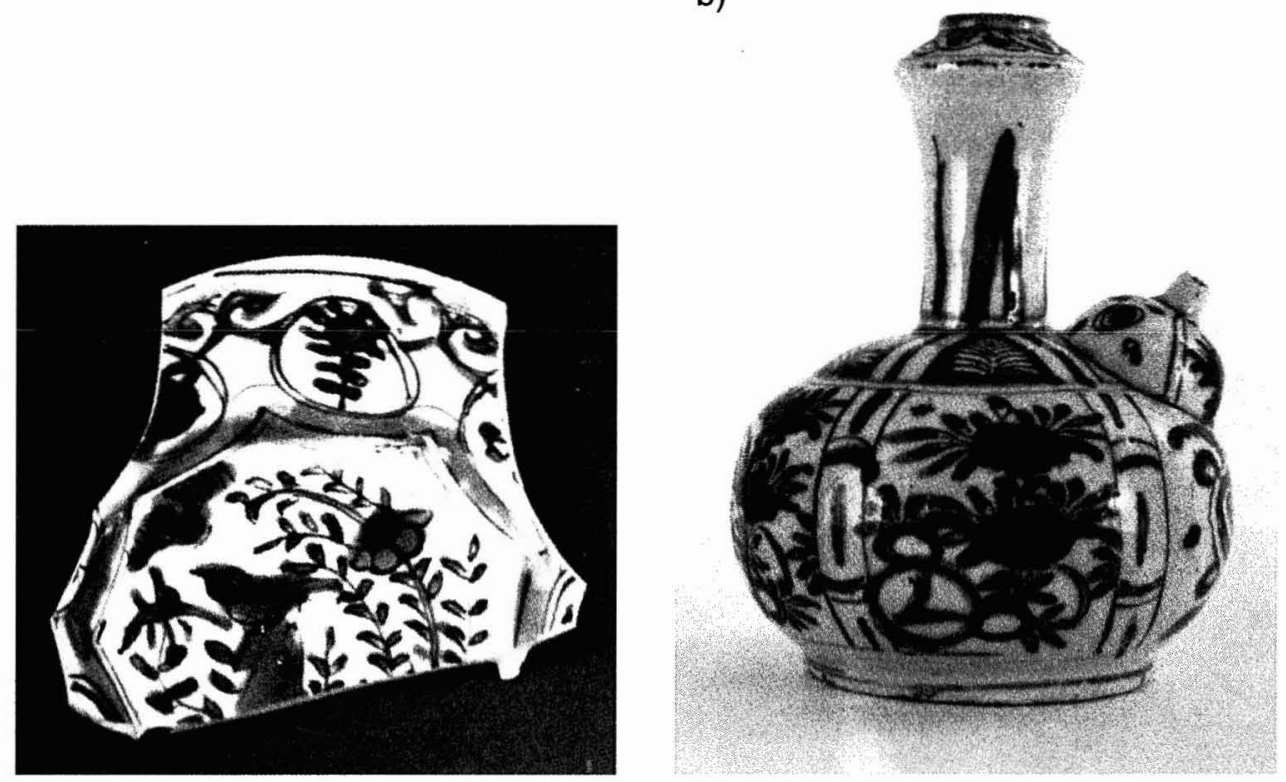

Fig. 6. Chinese blue-and-white porcelain: a: fragment of a dish from the Dejima site cluster (after Nagasaki Shiritsu Hakubutsukan 2000:53, fig. 1-5-30); b: kendi of unknown provenance (courtesy of the Museum of East Asian Art, Cologne).

and lancetlike leaves around the neck (Fig. 6b). The way in which the decoration was applied is similar to the examples discussed. The kendi bottle was classified as belonging to the so-called transitional wares, typologically positioned between Ming and Qing (清) (1644-1912) styles and produced for the Southeast Asian markets in the early seventeenth century (Goepper 1968:340). The Yamami bottle, against this background, was certainly part of the crockery used by a ship's team that sailed around the year 1600 or slightly later and came directly from Southeast Asia, as the large quantity of Thai wares has already indicated (cf. Kyūshū-Okinawa 2002:23).

The fragment of a blue-and-white dish found at Yamami, however, is suggested to be of earlier origin, from the beginning or middle sixteenth century (Kyūshū-Okinawa 2002:22-23). The design of the dish is applied in a silvergrayish underglaze blue (Fig. 7a,b,c). The petal-formed rim is decorated with two narrow encircling lines and an additional, faintly wavelike stripe, while the center of the dish shows some simple arabesques grouped around a medallion bearing threefold cross-shaped lines.

This specific kind of arabesque is also present on a Ming period blue-andwhite cup excavated at Hakata (Fig. 7d) (Fukuoka-shi Kyōiku Iinkai 1990:39). It was not possible, though, to find a comparative piece for the rather simple central medallion. The petal-formed rim, on the other hand, as well as the silver-grayish blue-a result of burning that has malfunctioned-both appear to be common elements of wares from the Wanli period, just like the blurred color strokes, 
a)

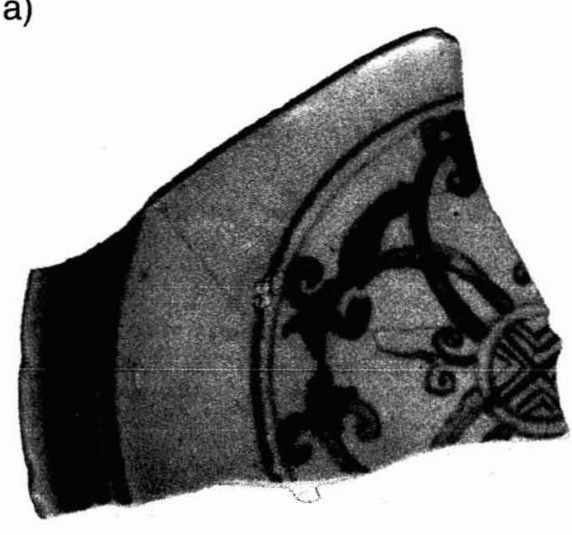

b)
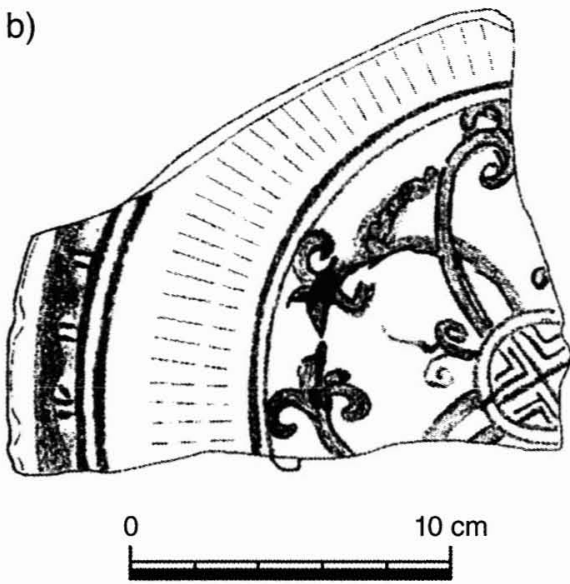

C)
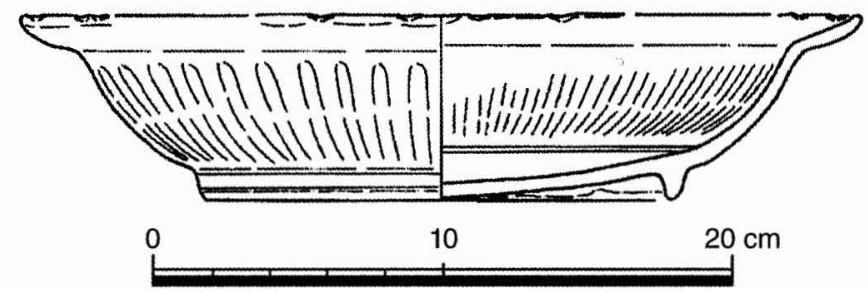

e)

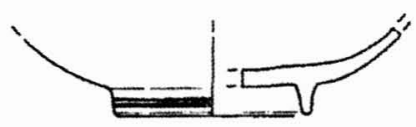

d)

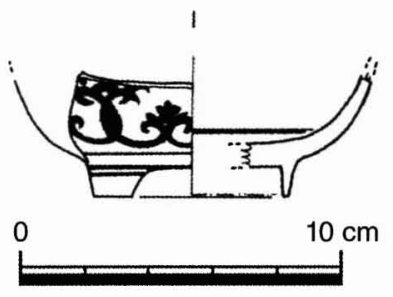

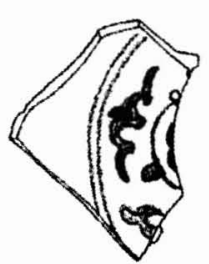

0

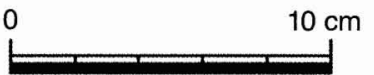

Fig. 7. Chinese blue-and-white porcelain: $a, b$, and c: fragment of a dish from Yamami site (photo: Seyock 2004, Ojika History and Folk Museum; b and c: after Kyūshū-Okinawa 2002:19, fig. 8/44); d: cup fragment from the Hakata site cluster (after Fukuoka Kyōiku Iinkai 1990:39, fig. 25/24); e: cup fragment from Yamami site (after Kyūshū-Okinawa $2002: 19$, fig. 8/43).

which are again extant here. In comparison, the complex of the Royal Captain junk raised near Palawan (Philippines) yielded petal-rimmed blue-and-white dishes of comparable design that show a rather wide range of different intensities of cobalt blue (Goddio 1997:115-119; see also Goepper 1967:339). It seems likely, therefore, to assume a production date of the Yamami dish nearer to that for the bottle. 
a)

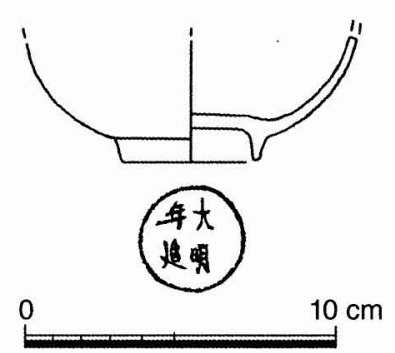

b)

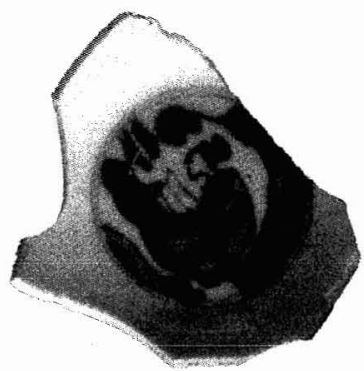

c)

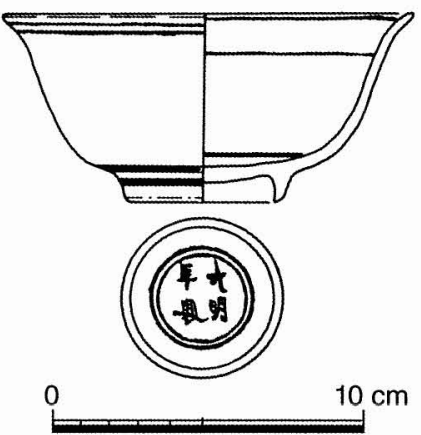

Fig. 8. Blue-and-white porcelain: a and b: (Japanese?) cup fragment from Yamami site (after Kyūshū-Okinawa 2002:19, fig. 8/42; photo: Seyock 2004, Ojika History and Folk Museum); c: Chinese cup from the Hakata site cluster (after Fukuoka Kyōiku Iinkai 1991: 55, fig. 59/3).

The same may apply for a cup fragment that bears a simple arabesque design in a silver-grayish blue around a central medallion (Fig. 7e). The exterior base is decorated with two circular lines (Kyūshū-Okinawa 2002:22).

Placing the origin of a teacup (Jap. wan 碗) fragment made of fine, white, quality paste is rather difficult (Kyūshū-Okinawa 2002:22). The interior base depicts a hermit (Jap. sennin 仙人) sitting underneath a pine tree (Fig. 8a,b); according to Crick, this was a common motif for Chinese export wares at the end of the sixteenth century. The hermit motif also appears on some dishes from the Royal Captain cargo (Crick 1997:153; Goddio 1997:116-117), as well as on a Jingdezhen dish excavated at the Manzai-machi (万才町) site in Nagasaki (Nagasaki-shi Maizō Bunkazai 1996:44, 60, fig. 30), or a similar piece from the sixtieth Hakata campaign (Fukuoka-shi Kyōiku Iinkai 1992:100-102, fig. 605). Both date as early as the late fourteenth century.

The intensive blue coloring of the Yamami fragment, however, bears a tinge of purple-not typically seen on Jingdezhen wares. The cup also bears the mark “dai-Ming-nian zao 大明年造” (made in the great Ming dynasty) on the exterior base, which would settle the question of its origin and date, were not the reign missing. Hobson (1976:213-214) has already pointed out that Ming-period date marks usually contain six Chinese characters: the aforementioned, with a possible alternative last character, plus the reign period positioned in the middle part of the date mark. Examples of these marks can be seen on the blue-and-white cups found at the Kushima Castle ruins (㺵島城跡) in Nagasaki, which date from the reign period of Chenghua (成化) (1465-1487) (Nagasaki-ken Kyōiku Iinkai $2002: 22$, figs. 145,149 ), or on a piece from the same period found at the Ima and Karō elite residential site in Izuhara (Nagasaki-ken Kyōiku Iinkai 2004:24, 25, fig. 6).

In the case of using a four-character mark, the first two were usually omitted, while a missing reign actually suggested Japanese workmanship of later centuries. Some comparable finds carrying the same abbreviated mark come from the Sakura-machi (桜町) excavations in Nagasaki. It is interesting to note that these pieces were dated eighteenth century (Nagasaki-ken Kyōiku Iinkai 1998b:1722, fig. 20:54), whereas a cup with exactly the same mark (Fig. 8c) uncovered 


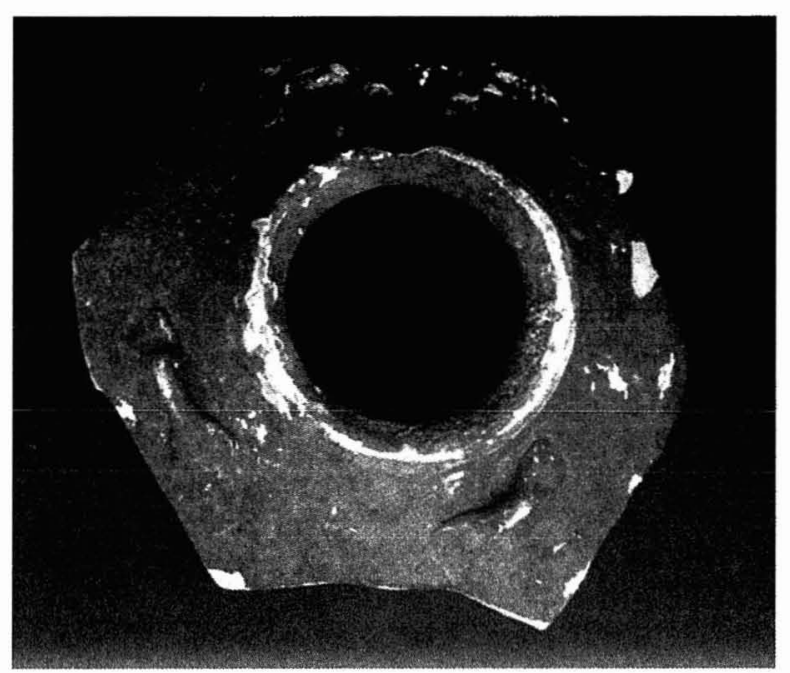

Fig. 9. Fragment of a Chinese jar with four lug handles from Yamami site (photo: Seyock 2004, Ojika History and Folk Museum).

during the forty-second campaign at Hakata is said to be an original piece of Ming china (Fukuoka-shi Kyōiku Iinkai 1991:54-55). As there is no unquestionable stratigraphy at Yamami-vertical or horizontal - the question of provenance for this porcelain piece remains unsolved.

The fragment of a four-handled jar made of fine, almost white paste, with blackish brown glaze on the inner and outer surface, seems to belong to a vessel that originates from South China (Fig. 9). Some other fragments showing a dark green glaze apparently come from the same region (Kyūshū-Okinawa 2002:21; cf. Crick 2002:222-223).

\section{Vietnam Wares}

Two shards found at Yamami possibly come from Vietnam. The body of a semispherical piece is of coarse quality and unglazed (Fig. 10a). Some marks on the inside of the reddish shard reveal its treatment on a potter's wheel. The site report suggests parallels to some bulbous lids found at Vietnamese sites (cf. Brown 2000:pl. Id). The other fragment may come from a jar of finer quality (Fig. $10 \mathrm{~b})$. The outer surface shows brown and yellow paint and the inner surface is brown with a tinge of purple (Kyūshū-Okinawa 2002:21-22).

Vietnamese kilns began to export ceramics around the fourteenth century. Similar to the situation in Thailand, Chinese refugees fleeing from the Mongol invasion of their homeland seem to have triggered the early export trade, which reached its heights in the fifteenth and sixteenth centuries in response to the maritime prohibition policy of the Ming. Compared to Thai jars and bowls, wares from Vietnamese kilns are, however, far less prominent in medieval or early modern complexes both in Japan and in Southeast Asia. According to Brown $(2000: 23)$, only 2 to 4 percent of the trade ceramics excavated in the Philippines are Vietnamese. It is difficult to decide whether this is attributed to a certain taste among the customers of fine ceramics or to the insufficient availability of Vietnamese wares. Given that pieces of Vietnamese porcelain (Jap. Betonamu tōjiki 
a)

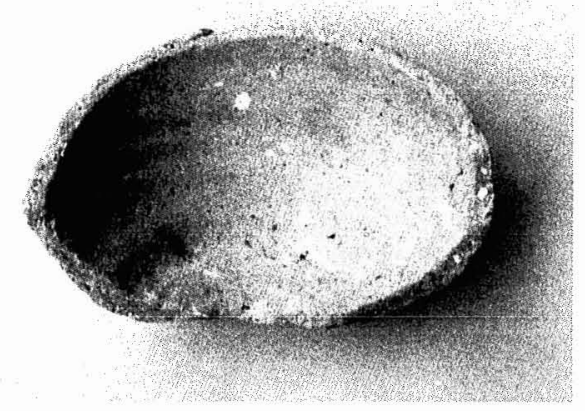

b)

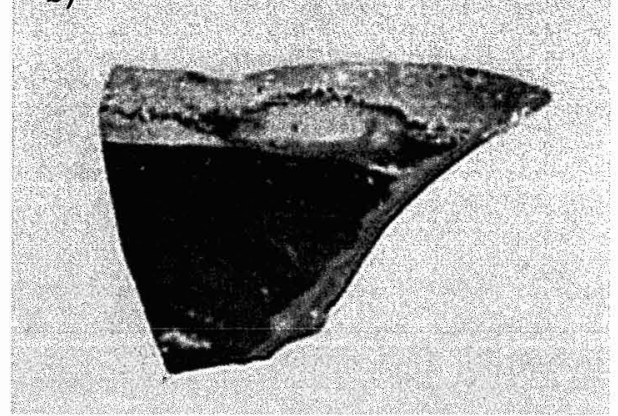

Fig. 10. Vietnamese wares from Yamami site: a: lid fragment (after Kyūshū-Okinawa 2002:36, pl. 66); b: jar fragment (after www.h3.dion.ne.jp/ uwarchae).

ベトナム陶磁器) are nevertheless rather widely spread in Southeast Asia as well as in Japan, even if only one or two remainders are extant in the respective complex, the latter explanation may be nearer to the truth.

In actuality, Brown (2000:29) explains, almost all of the known sites in Southeast Asia contained some pieces of Vietnamese ware. Richards (1995:45) describes Vietnamese iron-decorated wares and monochrome cream wares to be "among the most aesthetically appealing of Asian ceramics." As supply and demand was a basic pattern in the development of the trade ceramic industry in premodern East Asia, one can suggest either a production quantity quite inferior to the Thai industry and/or prices that could not compete with the kilns of Sawankhalok or Sisatchanalai.

In any case, the Yamami complex holds only two small pieces of ware, and these can scarcely be placed among the more typical and apparently highly valued Vietnamese products such as iron-painted or blue-and-white wares. While other sites in the vicinity - such as the Mizusaki (水崎) site on Tsushima Island (Seyock 2005), the Sakaemachi (栄町) site in Nagasaki (Nagasaki-ken Kyōiku Iinkai 2001 : 16, pl. 15, fig. 21), or the Hakata site cluster in Fukuoka (Fukuoka Kyōiku Iinkai 1992:107, 109, pl. 8, figs. 686-689)-produced fragments of fine Vietnamese teacups or dishes, the Yamami shards seem to belong to storage vessels, items of a different function and handling, which rather mirror the belongings of a ship's crew than the ceramic cargo of a trading ship.

\section{UNDERWATER ARCHAEOLOGY, TRADE CERAMICS, AND THE EAST ASIAN SEAS}

Underwater survey is still a rather recent development among the various fields of archaeological research in Japan. Although a lot of efforts have been made in search of maritime archaeological sources, to date only two off-coast sites around Kyūshū have experienced significant investigation: the Takashima underwater site (鷹島沖海底遺跡) in the Genkai Sea, which produced finds connected to the thirteenth-century attacks of the Mongols in northern Kyūshū (Nogami 2003; Takashima-chō Kyōiku Iinkai 2001), and the Yamami underwater site. Both surveys were carried out on the initiative of the Kyūshū and Okinawa Society for 
Underwater Archaeology, with the Takashima campaigns continuing, and there is certainly much more to expect from future research.

The Yamami complex added only 87 ceramic pieces to the collection of trade ceramics in western Japan, which is few in comparison to the wreck finds off the southwestern Korean coast or in the South China Sea. Even when compared to what has already been uncovered on the Gotō Islands alone, it is a rather small amount. Tsukahara $(2003: 16)$ reports 69 spots in the Gotōs where Chinese ceramics from the eleventh to seventeenth centuries have been identified. The material comprises celadon, white porcelain and early blue-and-white wares (Jap. sometsuke 染付) from the Tongan (同安) and Longquan (龍泉) kilns, as well as porcelain from Fujian Province (福建省), Guangdong Province (廣東省), Quanzhou (泉州), and Jiangnan (江南). Koryǒ (高麗) period (918-1392) Korean celadon is also a common find, though in smaller quantities (Tsukahara 1991:6).

On Uku Island, north of Ojika, tens of thousands of ceramic shards have been collected over the years. Most of them belong to Chinese celadon or white porcelain dishes and teacups made at Fujian and Longquan kilns between the twelfth and sixteenth centuries. Some celadon pieces originate from late Koryŏ period Korea. A connection to the activities of the (Jap.) wako (倭冦) - the "Japanese" pirates attacking Korean and Chinese coastlines-is suggested, particularly in the fourteenth to sixteenth centuries. The Gotōs are known to have been one of the most notorious pirate centers. Uku, the northernmost island, was probably the actual location of wako groups in the Gotōs (Aramata and Takahashi 1990:39). As has been shown in an earlier study on pirates and traders on Tsushima Island, c. $100 \mathrm{~km}$ north of the Gotōs, piracy and trade were closely connected during the late fourteenth to sixteenth centuries. In periods of political turmoil or famine, piracy was apparently an option for the islanders of western Japan (Seyock 2005).

Part of the ceramic heritage of the Gotōs was passed on by tradition. A tricolor glazed covered dish with incised flower motif (Jap. sansai inkoku kamon futamono 三彩陰刻花文蓋物), together with a bowl of the same design made in sixteenthto seventeenth-century South China, had long been in the possession of the Okino-kamishima shrine (沖ノ神島神社) on Uku Island. The shrine also kept two Ming-period celadon pieces, a dish and a bowl, and also eight beautiful, olive green or brown to black glazed South Chinese storage jars, some with loop handles and lids (Fig. 11) (Nagasaki-ken Kita-Matasuura-gun Ojika-chō Kyōiku Iinkai 2000:22-28). ${ }^{7}$ The pieces are now on display in the History and Folk Museum on Ojika Island. Although most of the ceramic finds come from the northern part of the Gotō Island chain, the ruins of Ishida Castle (石田城跡) as well as the Ōhama (大浜) site on Fukue Island (福江島), the main island of the Gotōs, also recently yielded trade ceramic pieces. While the Ishida Castle ruins produced only a few examples purchased from early Chosŏn (朝鮮) period (1392-1910) Korea and from South China, at the Ōhama site 145 trade ceramic shards from the Yuezhou (越州), Tongan, and Longquan kilns (eleventh to twelfth centuries) were uncovered, as well as Koryŏ celadon and Chosŏn unglazed stoneware from a period up to the sixteenth century (Nagasaki-ken Kyōiku Iinkai 1997 :31-32; Nagasaki-ken Kyōiku Iinkai 1998a:47-51).

Much of the trade ceramic heritage of the Gotos- now stored in the archives of the Ojika History and Folk Museum as well as in the Ōmura (大村) City archive for cultural assets (Nagasaki Prefecture)—was collected during field surveys. 


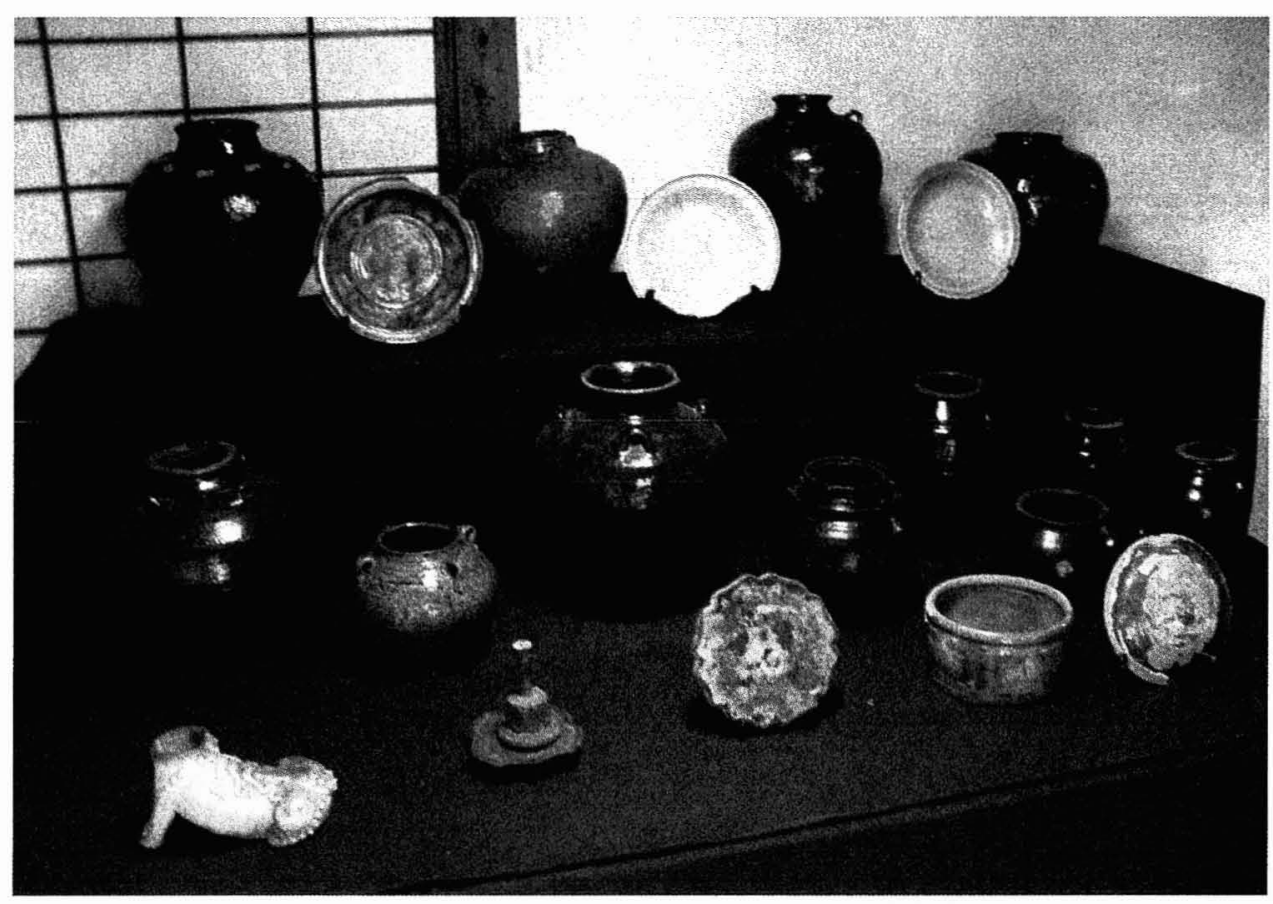

Fig. 11. Chinese jars, bowls and dishes from the Okinokamishima shrine (photo: Seyock 2004, Ojika History and Folk Museum).

It is still easy to find shard fragments at various spots scattered across the surface. The Gotō Islands, particularly the northern part, have been occupied by international trading vessels over many centuries, and much of the cargo seems to have been traded locally before or after the seagoing ships called at the ports of Hakata, Hirado, or Nagasaki.

One interesting point that allows some additional-and from an archaeological perspective, unexpected-insight into the importance of the maritime trade business around the Gotō Islands relates to the legend of the Kōrai sunken island. Once collected and written down by the famous Japanese folklore studies scholar Yanagita Kunio (柳田国男) (1875-1962), this local tale seems to have been triggered by the dominance of the ceramic trade in the East China Sea in premodern times. It says that once upon a time there was an island called Kōrai Island (高麗 島) where fine ceramics were produced at the Kōrai kiln. The islanders believed in Jizō (地蔵), the Buddhist guardian deity of children. One day, the local children played a practical joke on the worshipped Jizo statue, painting his face red, when suddenly a huge earthquake occurred. The whole island was swallowed then by the East China Sea. The place where the island is said to have sunk is today called the Kōrai Shoal (高麗瀬), of which the shallowest points lie some 4 to $6 \mathrm{~m}$ under water. Here, some $33 \mathrm{~km}$ west of Ojika Island, fishermen would regularly find Chinese ceramics in their nets (Tsukahara 1991).

The Kōrai Shoal was surveyed in the year 1977 by a group of divers originally interested in the sea fauna of the Gotōs and aware of the legendary sunken island, but no archaeologically usable finds or structures could be identified. Some of 
the researchers who were involved, however - in contrast to the expertise of an accompanying archaeologist-claimed to have found proof of a stone wall, a well, and the ruins of a Shintō gate (Yamamoto 1993). The sunken Kōrai Island thus offers enough opportunity to compete with the famous Yonaguni (与那国) underwater site off the southernmost island of Okinawa, a gigantic rock formation that regularly gains spectacular media coverage all over the world and is believed by certain groups to be the remnants of a sunken civilization.

For the ceramic trade, the Korai legend at least bears a core of truth, and there is much more-and especially more precise-evidence to be expected from the future research in underwater environments.

From historical sources we know that ships from the Chinese coast and from Southeast Asia sailed these waters regularly with cargoes made up of various items such as spices, fragrances and oils, fruits and nuts, exotic wood and animals, metals and minerals, textiles, military supplies, household articles, medical articles, and, of course, ceramics (Desroches 1997: 136; Lam 2002 : 48; Seyock 2005 : 100-103).

At archaeological sites, this variety of commodities is not evident in most cases. The Lena junk in the South China Sea, where lacquerware, beads, tusks, pepper, and a lot of metal objects have been found (Goddio 2002b:235-255; Scott 2002:256-257), or the Shin'an wreck off the South Korean coast with its metal and organic finds (Kungnip Haeyang Yumul Chŏngsigwan 2003:58-71) are exceptions to the rule. Japanese sites of this period seldom reveal more than the trade ceramic shards themselves when examined for relevant information on medieval and early modern maritime trade.

The Yamami find, nevertheless, is especially interesting in this regard, as it allows a small but direct insight into the maritime trading business in western Japan. Different from most of the fifteenth- to seventeenth-century sites in Japan, the Yamami complex exposes not the customers' side but the seafarers' side of this trade equation. While the collection of shards from the main seaports of Hakata and Nagasaki represents the full range of trade ceramics available from the Chinese mainland as well as from the Korean peninsula and Southeast Asia, the Yamami vessel points to a direct connection between western Japan and the Southeast Asian seas. The Ryūkyū Islands, where much of the intermediate trade was carried out during the fourteenth to mid-sixteenth centuries, were not necessarily involved anymore. Thai ships now came directly across the East China Sea, while in southern waters, as the Yamami complex shows, they called at various ports, using the full network of Southeast Asian markets, before they made their way north.

In view of the collected shards, it is so far not clear what kind of commodities the Yamami ship in fact carried north. A new survey was scheduled for August 2005, and additional finds may contribute to a further understanding of the ship's cargo, route, and destination. For the moment, the complex does not demonstrate typical trade ceramics, traded for their artistic value and responding to the taste of Japanese connoisseurs. The Yamami complex contains mainly large Thai storage containers, the actual commodities having been lost and, moreover, part of the ship team's crockery. One should therefore take into account the possibility that part of what is commonly categorized as "trade ceramics" was actually never meant to be traded on-site. The actual function of the ceramic item, regardless of its origin or quality, does makes a difference for the interpretation of shifting modes in the purchase of trade ceramics and, consequently, for the inter- 
pretation of shifting trade networks. In view of the Yamami ceramics, the question remains: Are we actually observing the remnants of a sunken vessel here? The collection is small, and-as we know from traditional archaeological sitesporcelain and stoneware have been traded to Japan in large quantities. The Shin'an wreck demonstrates that ceramic cargoes comprised tens of thousands pieces as early as the thirteenth century.

Japanese merchants were importing porcelain and glazed and unglazed stoneware from China, Korea, and Southeast Asia-such as white and blue-and white porcelain tea cups, plates or small jars from Chinese kilns, iron-painted pieces from Vietnamese kilns, celadon dishes from the Longquan kilns or from Sisatchanalai, Sukhothai bowls with underglaze brown decoration, Punch'ŏng ware and unglazed jars from Korea, and so on-in huge amounts from the thirteenth century on. Up to the early seventeenth century, the knowledge of porcelain production actually was not extant on the Japanese islands, whereas the spreading of the tea ceremony fashion (Jap. chanoyu 茶の湯) among the wealthy bourgeoisie and the warrior class during the Muromachi period (1338-1573) greatly increased the demand for respective objects (Cort 1991:28; Seyock 2006).

Louise Allison Cort elaborated on Southeast Asian ceramics (Jap. namban 南 蛮), noting that they counted among the most valuable objects connected to a transforming tea ceremony in the sixteenth century. While "the grand display ... of Chinese ceramics, bronzes, and lacquers" was one of the major objectives of bourgeoisie gatherings at an earlier stage, a fashion for the more exotic, singular piece developed later in the sixteenth century (Cort 1991:28).

We should therefore expect a much larger and more valuable complex at Yamami in the case of the wreckage of a seagoing trading ship from Southeast Asia. As has been discussed, there are hints that part of the complex - if not the whole assemblage - was originally placed on a ship's deck. Unless part of a vessel is identified in future research, the suggestion of a sailing accident that did not end in the loss of a complete ship but merely cleared the deck of a ship in a hazardous situation may be nearer to what really happened at this spot. Historical sources, such as the Kai-hentai (see fn. 3), talk about emergency situations that led the crew of a respective vessel to throw commodities and ship's items overboard. For the year 1690, we learn about the fate of a ship from Siam (Thailand) bound for Japan:

During our recent voyage, though nothing happened at sea, we had to endure strong winds. From the twelfth day through the fifteenth day of the sixth month, adverse winds blew incessantly and to such an extent that the ship was on the verge of sinking and our lives were endangered. Fortunately, we narrowly escaped disaster. However, during the stormy weather we threw all our sundry cargo overboard (Ishii 1998:54-55).

An earlier ship from Siam, which reached Nagasaki in September 1686, experienced a similar situation:

This year, unlike other years, strong winds were blowing which endangered us several times. Our ship was on the verge of capsizing, so we threw some of our cargoes into the sea to reduce the weight of the ship. We managed to survive and reach this port [Nagasaki] (Ishii 1998:40).

In rare cases, moreover, it was possible to recover parts of cargoes completely lost during a storm. The Kai-hentai reports the shipwreck of a Siamese ship in 
1692 near Akashima Island (赤島) (Gotōs), situated only c. $10 \mathrm{~km}$ west of the Yamami site. The local people, "warriors ... as well as fishermen and farmers did their best to collect what was floating or sunken" (Ishii 1998:67). An archaeological survey of this specific spot, if actually identified, would in all probability produce a similarly limited collection of finds. The examples extracted from the Kai-hentai thus illustrate at least some of the interpretative approaches that could alternatively be applied to the underwater site of Yamami.

The main parts of the Yamami complex certainly originate from one of the earlier ships from Siam that sailed in the late sixteenth to early seventeenth century, during a period of upheaval, at a time when Ming China lifted its ban on maritime trade and European ships contributed further to a lively international market in the South China Sea. The Japanese coasts at that time were still open to foreign calls, and Southeast Asian ships had changed their Ryūkyūan route and sailed directly across the East China Sea toward Japanese ports.

In the late seventeenth and early eighteenth centuries, however, trade under the Tokugawa realm was, under threat of severe penalties, not to be conducted anywhere else than at Nagasaki, the only licensed port. When regularly interviewed by the Nagasaki authorities, the pilots of the incoming ships would vehemently deny any such activity (Ishii 1998), though it is questionable whether this claim would stand the archaeological evidence of the latter Tokugawa period.

In any case, the Yamami site would be the first find of a sunken trading vessel in Japanese waters from what is commonly called "the age of the seafarers"-or, in the words of Imanuel Wallerstein, the Pacific "world system" trade. "World system" in this context denotes the nations bordering on the East China Sea, connected by "trade networks extending far beyond the boundaries of individual political units" (Wallerstein 1984, after Renfrew and Bahn 1994:308-309) during the fifteenth to eighteenth centuries and working mainly along sea routes. This system, as has been pointed out, also comprises strong bonds with the South China Sea, where the maritime trade prohibition policy of early Ming China generated the international success of the Thai and Vietnamese ceramic products. The trade ceramic finds from the Yamami site and from the Gotōs as a whole, as well as from the surrounding coasts, well support this view of trade and Japan's role in it during this critical period.

\section{ACKNOWLEDGMENTS}

The research for this article was carried out in the framework of the project "The East Asian 'Mediterranean,' c. 1500-1800: A New Quality in the Development of Its Neighbouring Countries" (see http://www.eamh.net/). The project is subsidized by the VW Foundation (Volkswagenstiftung, Germany). The author also wishes to express her gratitude to the following individuals and institutions: Mr. Tsukahara Hiroshi (Ojika Board of Education, History and Folk Museum), Dr. Tawara Kanji (Tsushima Board of Education), Professor Miyamoto Kazuo (Kyūshū University, Department of Archaeology), the Ōmura Institute of Cultural Assets (Nagasaki Prefectural Government Office of Education), the Fukuoka City Archaeology Center (Hakata), and the Kyūshū-Okinawa Society for Underwater Archaeology. Without their kind support, this study would not have been possible. For the preparation of the maps and figures, I would like to thank Mr. Michael Moos (www.mm-histweb. de). 


\section{NOTES}

1. One problem connected to the salvage of junks in the South China Sea concerns modern treasure hunting. Auctions of porcelain cargoes lost during the centuries of world trade and recovered by modern high-tech diving companies-observed critically from the scientific community for good reasons - resulted in tremendous financial success, thus generating a kind of modern gold rush in pursuit of the porcelain treasures of Southeast and East Asia, the "white gold" of the seas. Its height certainly has been reached with the Tek Sing cargo find. The shipwreck of the early nineteenth century-lifted under dubious circumstances-yielded more than $350,000 \mathrm{ce}-$ ramic pieces of good quality. The estimated auction price of the cargo amounted to 35 million deutschmarks (http://www.dhm.de/pipermail/de/museum/2000-November/000519.htm, http:// www.gfbv.de/voelker/suedosta/teksing/basis.htm and the auction catalogue for the Tek Sing Treasures, Stuttgarter Kunstauktionshaus, ed. Dr. Fritz Nagel 2000).

2. Due to the chronology of research, other sources state much smaller amounts of coins (Seyock 2005 : 108). The number given here comes from the present flyer of the National Maritime Museum in Mokp'o. The museum catalogue (Kungnip Haeyang Yumul Chŏngsigwan 2003:58) speaks of 28 tons of coins and suggests a figure of up to 8 million.

3. The Kai-hentai (華夷變態), a manuscript collection connected to the international sea trade at Nagasaki, at least reports one shipwreck of a Siamese junk on its way to Nagasaki near Akashima Island (Gotōs) (Ishii 1998:67).

4. I am currently preparing a book-length study on trade ceramics in western Japan.

5. The "Noi River" (Jap. Noi kawa ノイ川) denotes one of the several river arms of the Chao Praya (Maenam) River system, the main stream of central Thailand. Two of the prominent kiln site clusters here are Singburi and Suphanburi.

6. The distinction between Pitsanulok jars and Singburi examples seems to be a somewhat thorny problem, as some specimens look very much alike, and Pitsanulok typology is possibly not very well established yet (cf. Brown 2000: pl. 43b and Richards 1995: 18, fig. 6). Their dating, however, is eminent also for the Yamami Site. Morimoto's earlier Singburi examples thus may be worth a second look in search of a possible Pitsanulok affiliation.

7. The original script of the report gives earlier dates for the trade ceramics. The dates were later corrected by Tsukahara Hiroshi (handwritten corrections).

\section{REFERENCES}

Aramata Hiroshi, AND TAKahashi KŌMEI 荒俣宏・高橋公明

1990 Wajin Higashi-Shinakai o yuku: Tsuiseki, nazo no wakō shūdan 倭人東シナ海をゆ <一追跡、謎の倭冦集団, in Rekishi tanjo 歴史誕生 (La Nouvelle Histoire du Japon) 2:32-57, ed. Rekishi tanjō shuzaihan 歴史誕生取材班 編. Tōkyō: Kadokawa Shoten 角川書店.

BAER, WINFRIED

1973 Zur Chinamode im Kunstgewerbe, in China und Europa: Chinaverstaendnis und Chinamode im 17. und 18. Jahrhundert: 48-60, ed. Verwaltung der staatlichen Schloesser und Gaerten. Berlin.

Brown, RoXanna M.

1975 Preliminary report of the Koh Khram sunken ship. Oriental Art 21(4):356-370.

2000 The Ceramics of South-East Asia: Their Dating and Identification, 2nd ed. Chicago: Art Media Resources.

Bushell, S. W.

1919 Chinese Art, vol. 2. Reprint of $1906 \mathrm{ed}$. Victoria and Albert Museum Handbooks. London: His Majesty's Stationery Office.

Cort, Louise Allison

1993 Buried and treasured in Japan: Another source for Thai ceramic history, in Thai Ceramics: The James and Elaine Connell Collection: 27-44, ed. Asian Art Museum of San Francisco. New York: Oxford University Press.

Crick, Monique

1997 Die Fracht der fuenf Dschunken: Eine Einfuehrung in die Kunst der Keramik von China, Vietnam und Thailand, in Weisses Gold: Versunken, Entdeckt, Geborgen: 139-156, ed. Franck Goddio. Goettingen, Germany: Steidl.

Desroches, JeAn-Paul

1997 China und der Ozean (10. bis 16. Jh.), in Weisses Gold: Versunken, Entdeckt, Geborgen: 127-137, ed. Franck Goddio. Goettingen, Germany: Steidl. 
Fukuoka-shi Kyōiku linkai 福岡市教育委員会 編, ed.

1991 Hakata 17: Hakata iseki-gun dai 42 ji hakkustu chōsa gaiho 博多17一博多遺跡群第42次発掘 調査概報, Fukuoka-shi maizō bunkazai chōsa hōkokusho dai 245 shū 福岡市埋蔵文化財 調查報告書第245集. Fukuoka: Fukuoka-shi Kyōiku Iinkai 福岡市教育委員会.

1992 Hakata 30: Hakata iseki-gun dai 60 ji hakkutsu chōsa hōkokusho 博多30-博多遺跡群第60次 発掘調査報告書, Fukuoka-shi maizō bunkazai chōsa hōkokusho dai 285 shū 福岡市埋蔵 文化財調査報告書第285集. Fukuoka: Fukuoka-shi Kyōiku Iinkai 福岡市教育委員会.

GODdIO, FRANCK

1997 Die Royal-Captain-Dschunke, in Weisses Gold: Versunken, Entdeckt, Geborgen: 115-125, ed. Franck Goddio. Goettingen, Germany: Steidl.

2002a The wreck of the Lena shoal, in Lost at Sea: The Strange Route of the Lena Shoal Junk: 142, ed. Franck Goddio, Monique Crick, Peter Lam, Stacey Pierson, and Rosemary Scott. London: Periplus.

2002b Other artefacts, in Lost at Sea: The Strange Route of the Lena Shoal Junk: 235-255, ed. Franck Goddio, Monique Crick, Peter Lam, Stacey Pierson, and Rosemary Scott. London: Periplus.

GOEPPER, ROGER

1968 Kunst und Kunsthandwerk Ostasiens: Ein Handbuch für Sammler und Liebhaber. Muenchen, Germany: Keysersche Verlagsbuchhandlung.

GuY, JoHN

1993a The ceramics of central Thailand, in Thai Ceramics: The James and Elaine Connell Collection: 1-7, ed. Asian Art Museum of San Francisco. New York: Oxford University Press.

1993b Thai ceramics in Southeast Asian trade, in Thai Ceramics: The James and Elaine Connell Collection: 8-13, ed. Asian Art Museum of San Francisco. New York: Oxford University Press.

Hesemann, SABINe

1998 China, in Ostasiatische Kunst, vol. 1:8-265, ed. Gabriele Fahr-Becker. Koeln, Germany: Koenemann.

Hobson, R. L.

1976 Chinese Pottery and Porcelain: An Account of the Potter's Art in China from Primitive Times to the Present Day. Reprint of 1915 ed. New York: Dover Publications.

ISHII YONEO, ED.

1998 The Junk Trade from Southeast Asia: Translations from the Tōsen Fusetsu-gaki, 1674-1723.

Data Paper Series, Sources for the Economic History of Southeast Asia No. 6. Singapore: Institute of Southeast Asian Studies.

KANEKO TOMOKO 金子朋子

2004 Shutsudo tōjiki kara mita nankai bōeki no yōsō 出土陶磁器からみた南海貿易の様相, in Tsushima Yoshida iseki: Jōmon jidai iseki no hakkutsu chōsa 対馬吉田遺跡一縄文時代遺跡の 発掘調查: 54-76, ed. Miyamoto Kazuo 宮本一夫. Fukuoka: Kyūshū Daigaku Daigakuin Jinbun Kagaku Kenkyūin Kōkogaku Kenkyūshitsu 九州大学大学院人文科学研究院考古 学研究室.

Kungnip Haeyang Yumul Chŏngsigwan 궁닙해양유물전시관, ed.

2003 Pada ro ponun uri yǒksa 바다로보눈우리역사. Mokpo: Kungnip Haeyang Yumul Chŏngsigwan 궁닙해양유물전시관.

Kyūshū-Okinawa Suichū Kōkogaku Kyōkai and Ojika-chō Kyōiku Iinkai 九州・沖縄水中考古学 協会 - 小值賀町教育委員会 編, eds.

2002 Yamami okikaitei iseki: Ojika-chō Yamami okikaitei iseki kakunin chōsa hōkoku 山見沖海底遺 跡一小值賀町山見沖海底遺跡確認調查報告, Ojika-chō bunkazai chōsa hōkokusho dai 16 shū 小值賀町文化財調查報告書第16集. Ojika: Kyūshū-Okinawa Suichū Kōkogaku Kyōkai and Ojika-chō Kyōiku Iinkai 九州・沖縄水中考古学協会一小值賀町教育委員 会.

LEDDEROSE, LOTHAR

2004 Chinesische Kunst aus der Fabrik: Seide, Lack und Porzellan, in Der Brockhaus Multimedial, s.v.: ed. F. A. Brockhaus. Mannheim, Germany: F. A. Brockhaus.

Morimoto Asako 森本朝子

2000 Nihon shutsudo no Tōnan Ajia san tōji no yōsō 日本出土の東南アジア産陶磁の様相. Bōeki Töji Kenkȳu 貿易陶磁研究 (Trade Ceramics Studies) 20:123-133.

MukaI Kō

2001 向井互 Kuramu-tō oki chinbotsuen クラム島沖沈没船. Kikan Kōkogaku 季刊考古学 (Archaeology Quarterly) 75:64-65. 
Nagasaki-ken Kita-Matasuura-gun Ojika-chō Kyōiku Iinkai 長崎県北松浦郡小值賀町教育委員会 編, ed.

2000 Sōzu tonoshita iseki chōsa gaihō 相津殿下遺跡調查概報, Ojika-chō bunkazai chōsa hōkokusho dai 14 shū 小値賀町文化財調査報告書第14集. Ojika: Ojika-chō Kyōiku Iinkai 小値賀町教育委員会.

Nagasaki-ken Kyōiku Iinkai 長崎県教育委員会編, ed.

1997 Ishida-jō-ato: Kenritsu Gotō kōtō gakkō kentai kōji ni tomonau kinkyū hakkutsu chōsa hōkokusho 石田城跡一県立五島高等学校建替工事に伴亏緊急発掘調査報告書, Nagasaki-ken bunkazai chōsa hōkokusho dai 139 shū 長崎県文化財調查報告書第139集. Nagasaki: Nagasaki-ken Kyōiku Iinkai 長崎県教育委員会.

1998a Ōhama iseki 大浜遺跡, Nagasaki-ken bunkazai chōsa hōkokusho dai 141 shū 長崎県文化 財調查報告書第141集. Nagasaki: Nagasaki-ken Kyōiku Iinkai 長崎県教育委員会.

1998b Sakura-machi iseki: Nagasaki-ken keisatsu kansha kensetsu ni tomonau hakkutsu chōsa hökokusho 桜町遺跡一長崎県警察官舎建設に伴う発掘調査報告書, Nagasaki-ken bunkazai chōsa hōkokusho dai 144 shū 長崎県文化財調査報告書第144集. Nagasaki: Nagasaki-ken Kyō iku linkai 長崎県教育委員会.

2001 Sakaemachi iseki: Kyū Fukuromachi, shiritsu Nagasaki kōtō gakkō sekichi 栄町遺跡一旧袋 町、市立長崎高等学校跡地, Nagasaki-ken bunkazai chōsa hōkokusho dai 162 shū 長崎県文化財調査報告書第162集. Nagasaki: Nagasaki-ken Kyōiku Iinkai 長崎県教育 委員会.

2002 Kushima-jō-ato 玖島城跡. Nagasaki: Nagasaki-ken Kyōiku Iinkai 長崎県教育委員会.

2004 Ima-yashiki-karō-yashiki-ato: Toshi keikaku dōro Izuhara tōtō Mitsushima-sen dōro kaichiku kōji ni tomonau maizō bunkazai hakkutsu hōkoku 今屋敷家老屋敷跡一都市計画道路誉原豆䤑 美津島線道路改築工事に伴う埋蔵文化財発掘調査報告, Nagasaki-ken bunkazai chōsa hōkokusho dai 178 shū 長崎県文化財調查報告書第178集. Nagasaki: Nagasaki-ken Kyōiku Iinkai 長崎県教育委員会.

Nagasaki-shi Maizō Bunkazai Chōsa Kyōgikai 長崎市埋蔵文化財調查協議会 編, ed.

1996 Manzaimachi iseki: Asahi seimei biru kensetsu ni tomonau maizō bunkazai chōsa hōkokusho 万才 遺跡一朝日生命ビル建設に伴う埋藏文化財調査報告書. Nagasaki: Nagasaki-shi Maizō Bunkazai Chōsa Kyōgikai 長崎市埋蔵文化財調査協議会.

Nagasaki Shiritsu Hakubutsukan 長崎市立博物館 編, ed.

2000 Dai Dejima ten-Nichi-Ran kōryū 400 shūnen kinen tenrankai zuroku: Raiden, Nagasaki, Edo, ikoku bunka no madoguchi 大出島展・日蘭交流 400 周年記念展覧会図録一ライデ ン・長崎・江戸・異国文化の空口 (The Great Dejima Exhibition in Commemoration of the 400th Anniversary of Exchange between Japan and the Netherlands, Gateways of Foreign Culture-Leiden, Nagasaki, and Edo). Nagasaki: Nagasaki Shiritsu Hakubutsukan 長崎市立博物館.

NAgel, Fritz, ED.

2000 Nagel Auctions: Tek Sing Treasures (Nagel Auktionen: Der Schatz der Tek Sing). Stuttgart: Stuttgarter Kunstauktionshaus.

NeAve-Hill, W.B.R.

1975 Chinese Ceramics. New York: St. Martin's Press.

NOGAMI TAKENORI

2003 Chinbotsusen ni miru kaijō kōeki 沈没船に見る海上交易, in Sengoku jidai no kōkogaku 戦国時代の考古学: 485-494, ed. Ono Masatoshi and Hagiwara Mitsuo 小野正敏・萩原 三雄 編. Tōkyō: Kōshi Shoin 高志書院.

Pierson, StAcey

2002 Industrial ceramics in China: Ceramic production at Jingdezhen from the 10th to the 16th Century, in Lost at Sea: The Strange Route of the Lena Shoal Junk: 59-70, ed. Franck Goddio, Monique Crick, Peter Lam, Stacey Pierson, and Rosemary Scott. London: Periplus.

Rawson, Jessica, and Jane Portal

1992 Luxuries for trade, in The British Museum Book of Chinese Art: 256-291, ed. Jessica Rawson. London: British Museum Press.

Renfrew, Colin, and Paul Bahn

1991 Archaeology: Theories, Methods and Practice. London: Thames and Hudson.

RichaRdS, DICK

1995 South-East Asian Ceramics. Thai, Vietnamese and Khmer: From the Collection of the Art Gallery of South Australia. Photography by Clayton Glen. New York: Oxford University Press. 
SCOTT, ROSEMARY E.

2002 Connoisseurship and commerce, in Lost at Sea: The Strange Route of the Lena Shoal Junk: 91-95, ed. Franck Goddio, Monique Crick, Peter Lam, Stacey Pierson, and Rosemary Scott. London: Periplus.

SEYOCK, BARBARA

2004 Auf den Spuren der Ostbarbaren: Zur Archaeologie protohistorischer Kulturen in Suedkorea und Westjapan. Tuebinger interkulturelle und linguistische Japanstudien, vol. 8. Muenster, Germany: Lit-Verlag.

2005 Pirates and traders on Tsushima Island during the late 14th to early 16th century: As seen from historical and archaeological perspectives, in Trade and Transfer across the East Asian. Mediterranean, ed. Angela Schottenhammer. Vol. 1 of East Asian Maritime History: 91126. Wiesbaden, Germany: Harrassowitz.

2006 Trade ceramics from selected sites in western Japan: Late 14th to 17th centuries. Bulletin of the Indo-Pacific Prehistory Association 26 (BIPPA) 26:131-139.

Sotнeву \& Co., ED.

1974 Catalogue of Oriental Ceramics, Date of Sale: Tuesday, 30th April, 1974. London: Sotheby \& Co.

Takashima-chō Kyōiku Iinkai and Kyūshū-Okinawa Suichū Kōkogaku Kyōkai 鷹島町教育委員 会一九州・沖縄水中考古学協会 編, eds.

2001 Takashima. Mōko shūrai, soshite kamikaze no shima 鷹島・蒙古襲来・そして神風の島. Takashima: Takashima-chō Kyōiku Iinkai and Kyūshū-Okinawa Suichū Kōkogaku Kyōkai 鷹島町教育委員会一九州・沖縄水中考古学協会.

TSUKAHARA Hiroshi 塚原博

1991 Kaibotsu shita tōjiki no shima no densetsu 海没した陶磁器の島の伝説. Newsletter of the Kyushu and Okinawa Society for Underwater Archaeology 2,1:5-8.

2003 Gotō rettō no bōeki tōji shutsudo iseki, Gotō rettō no suichū kōkogaku-teki kankyō 五島列島の貿易陶磁出土遺跡、五島列島の水中考古学的環境, in Watatsumi no taimukapuseru, Ajia no suichū kōkogaku saizensen, わたつみのタイムカプセルーアジアの水中 考古学最前線, Kyūshū-Okinawa Suichū Kōkogaku Kyōkai dai 2 kai gakujutsu shinpojiumu 九州・沖縄水中考古学協会第2回学術シンボジウム]: 15-16, ed. Kyūshū-Okinawa Suichū Kōkogaku Kyōkai 九州・沖縄水中考古学協会 編. Fukuoka: Kyūshū-Okinawa Suichū Kōkogaku Kyōkai 九州・沖縄水中考古学協会.

VAINKER, Shelagh

1992 Ceramics for use, in The British Museum Book of Chinese Art: 212-255, ed. Jessica Rawson. London: British Museum Press.

VAN Der Pijl-Kete, C. L., ED.

1982 The Ceramic Load of the "Witte Leeuw" (1613). Amsterdam: Rijksmuseum Amsterdam.

Yамамото Aizō

1993 Chinkō densetsu no shima: Kōrai sōkon chōsa omoide 沈降伝説の島一高麗曾根調查想 い出. Newsletter of the Kyushu and Okinawa Society for Underwater Archaeology 2(4):4-8.

Websites:

http://www.h3.dion.ne.jp/ uwarchae

http://www.dhm.de/pipermail/demuseum/2000-November/000519.htm

http://www.gfbv.de/voelker/suedosta/teksing/basis.htm

\section{ABSTRACT}

Underwater archaeology is still a new development in Japan, and to date only a few sites have experienced significant investigation. One of them is the recently surveyed Yamami underwater site on the Goto Islands, which yielded sixteenth- to seventeenth-century trade ceramics from Thailand and Vietnam, as well as from the Jingdezhen kilns in China. After an introduction to the subject of ceramic trade and underwater archaeology in East Asia, the article reviews the ceramic pieces of the Yamami site in detail and links them to comparable finds from various sites in western Japan, such as from the main ports of Hakata and Nagasaki, along with examples from different international museum collections and wreck finds from the South China Sea. After also consulting historical sources, such as the Kai-hentai, the study 
develops a fresh interpretative approach toward the Yamami find, and-in a broader perspective-suggests strong bonds between the late medieval and early modern Japanese markets and the lively networks of the South China Sea. KeYwords: Japan, trade ceramics, underwater archaeology, medieval period, early modern period, porcelain, stoneware, Southeast Asia, China, Korea, maritime trade, Hakata, Nagasaki, Gotō Islands. 